\title{
La presencia francesa en el Perú
}

\section{Pascal Riviale}

\section{(2) OpenEdition}

\section{Journals}

Edición electrónica

URL: http://journals.openedition.org/bifea/5552

DOI: 10.4000/bifea.5552

ISSN: 2076-5827

\section{Editor}

Institut Français d'Études Andines

\section{Edición impresa}

Fecha de publicación: 1 agosto 2005

Paginación: 264

ISSN: 0303-7495

\section{Referencia electrónica}

Pascal Riviale, « La presencia francesa en el Perú », Bulletin de l'Institut français d'études andines [En línea], 34 (2) | 2005, Publicado el 08 agosto 2005, consultado el 05 diciembre 2020. URL : http:// journals.openedition.org/bifea/5552 ; DOI : https://doi.org/10.4000/bifea.5552

\section{(c) $(1) \odot$}

Les contenus du Bulletin de l'Institut français d'études andines sont mis à disposition selon les termes de la licence Creative Commons Attribution - Pas d'Utilisation Commerciale - Pas de Modification 4.0 International. 


\section{LA PRESENCIA FRANCESA EN EL PERÚ}

Del 4 al 8 de julio de 2005 tuvo lugar en Lima un coloquio dedicado a la presencia francesa en el Perú. Este coloquio estuvo organizado conjuntamente por el Instituto Francés de Estudios Andinos y el Congreso del Perú. El ojetivo de dicha reunión era analizar los orígenes, el desarrollo y la resonancia actual de la presencia francesa en el Perú.

La primera sesión, realizada el 4 de julio en el hemiciclo Porras Barrenechea en el Congreso del Perú, presidida por Anne Marie Hocquenghem, estuvo dedicada a la inmigración francesa. La sesión fue abierta con unas palabras de introducción de Natale Amprimo Plá, primer vice presidente del Congreso de la República, luego las de Jean-Paul Angelier, embajador de Francia en el Perú. En la primera conferencia, Pascal Riviale presentó las características generales de la inmigración francesa al Perú en el siglo XIX (importancia numérica, principales regiones de origen y grandes sectores profesionales ocupados por estos inmigrantes). En contrapunto, Henri Godard, director del IFEA, propuso un análisis estadístico y cartográfico de la presencia actual de la comunidad francesa. En la última conferencia de la tarde, Francisco Durand nos dio el ejemplo muy bien documentado de las familias Durand y Flórez, ilustrando, de un lado, el caso de una implantación muy antigua (a mediados del siglo XVIII para la familia Durand), y de otro, una influencia francesa muy marcada (para la familia Flórez).

El segundo día (el 5 de julio en la Alianza Francesa de Miraflores, bajo la presidencia sucesiva de Margarita Guerra, Rodrigo Montoya, Gisèle Roubaud y Sandro Patrucco) fue la ocasión para mostrar, a través de un gran número de conferencias, las diversas manifestaciones de la influencia francesa en el Perú durante los períodos colonial y republicano. Mientras que Sandro Patrucco presentó algunos testimonios de la presencia de franceses durante el Vireynato y Arnaldo Mera se interesó en los comienzos de la implantación commercial luego de la Independencia, las otras intervenciones pusieron el énfasis en la influencia francesa de tal como puede ser ser identificada con sus facetas más diversas. Primero, los franceses en tanto acores y transmisores de innovación: los arquitectos e ingenieros (conferencias de Juan Gunther y José García Bryce), Courret y la fotografía (Herman Schwarz). La recepción de la cultura francesa en el seno de la sociedad peruana se pudo observar, por supuesto, a través de manifestaciones materiales: lo son así la moda en la vestimenta del período colonial (Scarlett O'Phelan), la difusión de cafés como nuevo lugar de modernidad y de socialización (Oswaldo Holguin) y, finalmente, la gastronomía vista como un tipo de marcador social y un vector de imaginario (Mariano Valderrama). Pero también, y sobre todo, se observa a través de las ideas. Mientras que José Ragas propuso una evaluación de la recepción de las ideas revolucionarias de 1789 y 1848, Francesca Denegri se detuvo en el ejemplo del viaje de Flora Tristán al Perú como revelador de sus teorías feministas y sociales en desarrollo. Marcos Cueto nos demostró la influencia de la medicina francesa en el siglo XIX a través del caso de Ernesto Odriozola. Finalmente, este día, muy denso en información y reflecciones, fue cerrado con un análisis del pensamiento filosófico de Rousseau (Augusto Ruiz Zevallos) y de Tocqueville (Sinesio López) y su huella en el Perú.

El ultimo día, el 8 de julio, estuvo dedicado a una evaluación crítica de la investigación francesa en el Perú estas últimas décadas y de su impacto en este país en algunos grandes sectores de las ciencias humanas y sociales: la sociología (Denis Sulmont), la antropología (Carmen Salazar), la política (Hugo Neira) y la economía (Gonzalo García). En contrapunto, la intervención final de Emmanuel Bonnet, presidente de la Cámara de Comercio e Industria Franco-Peruana, sobre la presencia económica francesa en el Perú, nos podría llevar a concluir que si bien esta presencia se mantuvo relativamente discreta, es la influencia intelectual y científica la que, sin duda, ha marcado la historia de las relaciones entre nuestras dos naciones. El discurso de clausura pronunciado por el ministro peruano de relaciones exteriores, Manuel Rodriguez Cuadros, rememoró los fuertes rastros dejados por algunos de estos «transmisores culturales» evocados a lo largo de todo el coloquio rico en encuentros e investigaciones en elaboración o en desarrollo. 